\title{
Sarcopenia as Prognostic Factor in Lung Cancer Patients: A Systematic Review and Meta-analysis
}

\author{
JUDITH BUENTZEL ${ }^{1}$, JUDITH HEINZ ${ }^{2}$, ANNALEN BLECKMANN ${ }^{3}$, CHRISTOPH BAUER ${ }^{4}$, \\ CHRISTIAN RÖVER ${ }^{2}$, HANIBAL BOHNENBERGER ${ }^{5}$, SHEKHAR SAHA ${ }^{6}$, \\ MARC HINTERTHANER ${ }^{6}$, HASSINA BARAKI ${ }^{6}$, INGO KUTSCHKA ${ }^{6}$ and ALEXANDER EMMERT ${ }^{6}$ \\ ${ }^{1}$ Department of Haematology and Medical Oncology, ${ }^{2}$ Department of Medical Statistics, \\ ${ }^{6}$ Department of Thoracic and Cardiovascular Surgery University Medical Center, \\ Georg-August University, Göttingen, Germany; \\ ${ }^{3}$ Comprehensive Cancer Center Münster, University Medical Center, University Münster, Münster, Germany; \\ ${ }^{4}$ Department of Nephrology and Hypertension, \\ Center for Internal Medicine and Medical Clinic III, Klinikum Fulda, Fulda, Germany; \\ ${ }^{5}$ Institute of Pathology, University Medical Centre, Göttingen, Germany
}

\begin{abstract}
Background/Aim: Sarcopenia describes the loss of skeletal muscle mass. While this condition is associated with a high mortality in cancer patients, its influence on survival is still underestimated. Patients and Methods: A systematic review for articles was performed using the PubMed database, Cochrane Library, Biomed Central, Science Direct and by manual search. We used data of overall survival in sarcopenic patients for assessing the death risk. We extracted hazard ratio estimates from univariate and multivariate Cox proportional hazards models for meta-analysis. Results: A total of 15 studies were eligible for meta-analysis including a total of 2,521 lung cancer patients. Univariate meta-analysis revealed a two-fold increased death risk in sarcopenic patients; multivariate meta-analysis yielded a significant, three-fold elevated risk of death. This higher mortality is independent of tumour stage. Conclusion: Muscle loss is an independent risk factor for increased death risk in lung cancer patients independent of cancer stage. This argues for implementing screening for sarcopenia into cancer care.
\end{abstract}

This article is freely accessible online.

Correspondence to: Alexander Emmert, Department of Thoracic and Cardiovascular Surgery, University Medical Center, GeorgAugust University, Robert-Koch-Str. 40, 37075 Göttingen, Germany. Tel: +49 5513966061, Fax: +49 5513913742, e-mail: alexander.emmert@med.uni-goettingen.de

Key Words: Sarcopenia, lung cancer, meta-analysis, prognosis, review.
Sarcopenia describes the age-related loss of muscle mass and strength starting during the fourth to fifth decade of life. It is defined as a muscle mass of at least two standard deviations below the mean muscle mass found in young healthy adults (1-3).

While often reported in the elderly, loss of muscle mass does also manifest in patients suffering from a chronical disease like congestive heart failure, chronical obstructive pulmonary disease, chronical renal failure or cancer. Muscle loss has a relevant impact on survival, especially in the latter group. The prevalence of sarcopenia in cancer patients depends on cancer entity, which is why a prevalence of $16 \%$ is described in breast cancer patients, whereas $71 \%$ of lung cancer patients under palliative therapy suffer from sarcopenia (4-6).

Muscle wasting is an unfavourable prognostic factor for cancer specific survival of rectum, liver, oesophagus, stomach or kidney cancer patients $(1,7)$. If muscle mass is maintained or increased, patients show a longer overall survival (5). Sarcopenia may be caused by several different factors; cancer, chemotherapy or locoregional impairment caused by surgery or radiation therapy, comorbidities, malnutrition or physical inactivity (8). Sarcopenia itself is also a risk factor for an increase in chemotoxicity and a decrease in therapy response (1). Physical activity prevents muscle wasting; a small pilot study showed that smartphones are a good tool to implement personalized physical activity programs and to increase physical activity of patients $(9,10)$. Sarcopenia is assessed by using Dual-energy X-ray absorptiometry scan (DEXA), bioelectrical impedance analysis (BIA) or computed tomography (2). Especially computed tomography is used routinely for investigations 
and follow-up in lung cancer patients and offers an elegant way to simultaneously assess sarcopenia by calculating the skeletal muscle mass index $(5,11-20)$.

Here, we investigated sarcopenia as a potential prognostic factor in lung cancer patients. We further analysed the influence of tumour stage, study design and an increase in muscle mass on patients' outcome.

\section{Patients and Methods}

Literature search and study selection. To identify relevant studies, we performed a systematic literature search in the bibliographic databases MEDLINE via PubMed (299 hits), BioMed Central (24 hits), Science Direct (331 hits) and Cochrane Library (26 hits) on 2nd May 2018. No language restrictions and no filters were applied to the search. The following search terms were used: ("lung cancer" OR "lung cancers" OR "pulmonary cancer" OR "pulmonary cancers" OR "lung neoplasm" OR "lung neoplasms" OR "lung neoplasm" (MeSH Terms)) AND ("sarcopenia" OR "sarcopenia" (MeSH Terms) OR "malnutrition" OR "malnutrition" (MeSH Terms)). The abstracts identified by the literature search were screened independently for inclusion and exclusion criteria by two investigators (JB and AE). If an abstract was judged as potentially relevant, the full-text of the publication was screened. Studies were included (I) if sarcopenia was assessed in lung cancer patients using DEXA, BIA or computed tomography, (II) if overall survival was reported and (III) if data were suitable for statistical analysis (refer also to subsection data extraction and meta-analyses). Reference lists of the publications fulfilling the inclusion criteria were also screened via hand search in order to identify additional studies.

Quality assessment. Since the meta-analysis was based on observational studies, we assessed the study's quality regarding three category groups, as recommended (20): selection of patients (low-risk in studies with consecutive inclusion of patients; high-risk mainly in retrospective studies without consecutive inclusion), description of outcome measurement (low-risk if the observation period for the endpoint mortality has been defined in the publication) and description of the covariate measurement (definition of the covariates included in the survival analyses; highrisk for studies without inclusion of covariates in the model; unknown risk for studies reporting multivariate analyses but without specification of the covariates, and low-risk for studies, which explained explicating the covariates of the multivariate models).

Data extraction and Meta-analyses. We extracted data on study design, recruitment time, number, gender and age of patients, cancer entity and cancer stage, treatment, method of assessing sarcopenia and the cut off for sarcopenia of the chosen method. As the measure of interest quantifying the effect of sarcopenia on overall survival we extracted hazard ratios from univariate and multivariate Cox proportional hazards models. We extracted point estimates and the associated confidence interval. The extracted hazard ratios were log-transformed and their standard errors were calculated from the reported $95 \%$ confidence intervals. The effect estimators were combined in a random effects model with inverse variance weighting and using a heterogeneity estimator of DerSimonian and Laird $(21,22)$. Heterogeneity between studies was examined by using the $\mathrm{I}^{2}$ statistic, quantifying inconsistency across studies. Tau ${ }^{2}$ was given as an estimator of the variance between studies in a random effect meta-analysis. The stability of the pooled results was examined by leaving out one study at a time and pooling the remaining effect measures. Separate metaanalyses have been conducted regarding inclusion of covariates in the cox proportional hazards models (univariate and multivariate). We conducted further a separate meta-analysis for studies including sarcopenia as continuous variable (per unit SMI/SMA or phase angle) in the Cox proportional hazards model. Subgroup analyses have been conducted regarding study design (retrospective and prospective) and tumour classification (if UICC classification was reported, UICC I to IIIa and UICC IIIB to IV). For this subgroup analyses point estimates and confidence intervals from univariate analyses have been used, since most of the studies indicated results from univariate analyses. If the estimator was only available from multivariate analysis we used this estimator. Subgroup analysis concerning the cancer type (non-small cell lung cancer and small cell lung cancer) was not possible since only one eligible study included patients with small cell lung cancer. In this case a sensitivity analysis was conducted excluding this study and re-pooling the results. Since only four studies were available including a measure of sarcopenia as a continuous variable, we did not conduct further subgroup analyses in this meta-analysis.

All analyses were performed using Review Manager (RevMan), Version 5.3, Copenhagen: The Nordic Cochrane Centre, The Cochrane Collaboration, 2014.

\section{Results}

Search results and characteristics of included studies. Ten retrospective studies and five prospective observational studies published between 2009 and May 2018 were included in this meta-analysis (Figure 1 and Table I). The number of patients included into the studies varied from 33 to 252 patients. In total we were able to include 2521 patients, and $60.5 \%$ were male. We included studies investigating patients with either NSCLC (non-small cell lung carcinoma; 13 studies), NSCLC and SCLC (small cell carcinoma; one study) or SCLC (one study). The group of NSCLC patients was heterogeneous, albeit studies did not analyse sarcopenia by sub-entities (adenocarcinoma, squamous cell carcinoma). Patients were treated either by surgery, chemotherapy, radiotherapy, targeted therapy or a combination of these. Surgical treatment was usually reserved for patients suffering from NSCLC I-IIIA, while chemo- and/ or radiotherapy was the treatment of choice in advanced cancer (UICC IIIB-IVB; refer also to Table I). Tumour stage for NSCLC was either described using the UICC classification (Ranging from I-IV) or the TNM classification (ranging from T1a-T2a). SCLC was classified as limited or extensive disease. Follow up time of patients included into these studies ranged from 90 days to follow up until death of patients. Studies assessed sarcopenia by using either computed tomography images for calculating the muscle area (L3/psoas, pectoral or Th12; 12 studies), BIA (two studies) or DEXA (one study; Table I). Studies used 

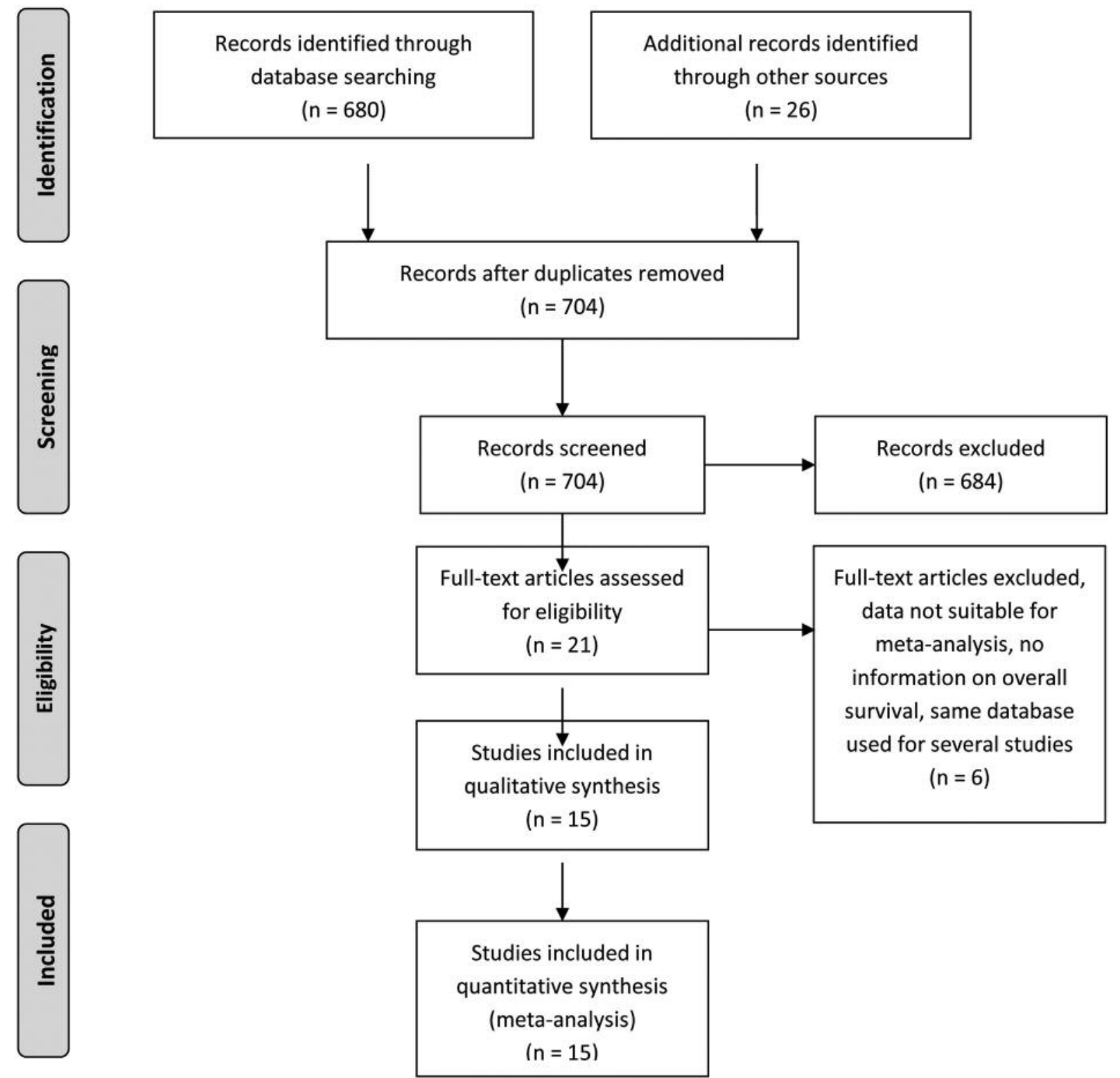

Figure 1. PRISMA flow-chart, describing the selection process. Studies were assessed by data-base screening and manual search. Duplicates were removed; studies not meeting the inclusion criteria were excluded. Of 21 studies eligible for analysis only 15 were suitable and included in quantitative synthesis.

univariate and/or multivariate Cox proportional hazards models for describing the impact of sarcopenia on overall survival. A meta-analysis of the influence of sarcopenia on disease-free survival was not possible, as only one study investigated the association of disease-free survival and sarcopenia (18).

Quality Assessment of included studies. The included studies were observational studies with retrospective $(n=10)$ and prospective study designs $(n=5)$. In half of these studies the inclusion of patients was not consecutive and a bias in patient selection cannot be excluded. In most studies the exact observation period of the outcome mortality was defined. In three publications we found no specification on outcome measurement. Most of the studies included covariates in the survival analyses, of which six studies reported the included covariates. Four studies did not account for covariates and were therefore classified as highrisk for bias. We did not exclude any of the identified studies from further analysis after quality assessment (Figure 2). 
Table I. Study characteristics.

\begin{tabular}{|c|c|c|c|c|c|c|c|c|}
\hline $\begin{array}{l}\text { Author, publication } \\
\text { year }\end{array}$ & $\begin{array}{l}\text { Study } \\
\text { design }\end{array}$ & Recruitment & $\begin{array}{c}\mathrm{N} \text { patients } \\
\text { (male/female) }\end{array}$ & $\begin{array}{c}\text { Age, } \\
\text { mean } \pm \text { SD }\end{array}$ & $\begin{array}{l}\text { Cancer, } \\
\text { stage }\end{array}$ & $\begin{array}{l}\text { Procedure, } \\
\text { follow-up } \\
\text { duration }\end{array}$ & Method & $\begin{array}{c}\mathrm{SMI}\left(\mathrm{cm}^{2} / \mathrm{m}^{2}\right) \\
\text { cut-off } \\
\text { sarcopenia }\end{array}$ \\
\hline $\begin{array}{l}\text { Bowden et al., } \\
2017\end{array}$ & $\begin{array}{l}\text { Retrospective } \\
\text { cohort }\end{array}$ & $2008-2010$ & $194(91 / 103)$ & $64(58-70) *$ & $\begin{array}{l}\text { NSCLC/SCLC, } \\
\text { I-IV, limited/ } \\
\text { extensive diseas }\end{array}$ & $\begin{array}{l}\text { CRT, } \\
90 \text { days }\end{array}$ & $\begin{array}{l}\text { CT Th4 } \\
\text { muscle index }\end{array}$ & $\begin{array}{l}\text { Cut-off male/female } \\
\text { as defined by } \\
\text { Prado et al. } 2008\end{array}$ \\
\hline $\begin{array}{l}\text { Chambard, } \\
2018\end{array}$ & $\begin{array}{l}\text { Prospective } \\
\text { cohort }\end{array}$ & Start 2011 & $64(48 / 16)$ & $65.1 \pm 11.4$ & NSCLC, IV & $\begin{array}{l}\text { CHT, targeted } \\
\text { therapy, }\end{array}$ & $\begin{array}{c}\text { DEXA } \\
\text { only }\end{array}$ & $\begin{array}{l}\text { DEXA sarcopenia } \\
\text { male }<7.26 \mathrm{~kg} / \mathrm{m}^{2}\end{array}$ \\
\hline$<5.45 \mathrm{~kg} / \mathrm{m}^{2}$ & & & & & & Until death & 49 patients & $\begin{array}{lllll}\mathrm{f} & \mathrm{e} & \mathrm{m} & \mathrm{a} & 1\end{array}$ \\
\hline $\begin{array}{l}\text { Gupta et al., } \\
2009\end{array}$ & Retrospective & 2001-2006 & $165(93 / 72)$ & No reference & $\begin{array}{l}\text { NSCLC, } \\
\text { IIIB-IV }\end{array}$ & $\begin{array}{c}\text { No reference, } \\
>1 \text { year }\end{array}$ & $\begin{array}{l}\text { Phase } \\
\text { angle }\end{array}$ & $\begin{array}{c}\text { Phase angle }>5.3^{\circ} v s . \\
\leq 5.3^{\circ} / \text { Phase angle } \\
>5.3^{\circ} \mathrm{vs} . \leq 5.3^{\circ}\end{array}$ \\
\hline $\begin{array}{l}\text { Kim et al., } \\
2015\end{array}$ & Retrospective & $2010-2014$ & $149(127 / 22)$ & $68.6 \pm 9.5$ & $\begin{array}{c}\text { SCLC, } \\
\text { Limited/ } \\
\text { extended disease }\end{array}$ & $\begin{array}{c}\mathrm{CHT} / \mathrm{RT} \\
\text { radiation, } \\
29 \text { months } \\
(\text { median })\end{array}$ & $\begin{array}{l}\text { CT L3 } \\
\text { muscle } \\
\text { index }\end{array}$ & $<55 /<39$ \\
\hline $\begin{array}{l}\text { Kinsey et al., } \\
2017\end{array}$ & Prospective & $2002-2006$ & $252(117 / 135)$ & $66.2 \pm 10.9$ & $\begin{array}{l}\text { NSCLC, } \\
\text { I-IV }\end{array}$ & $\begin{array}{l}\text { Surgery/CHT/ } \\
\text { RT, } 2412 \\
\text { days (median) }\end{array}$ & $\begin{array}{c}\text { CT } \\
\text { pectorales } \\
\text { muscle } \\
\text { area }\end{array}$ & $\begin{array}{l}\text { Pectoral muscle } \\
\text { area in } \mathrm{cm}^{2} / \\
\text { Pectoral muscle } \\
\text { area in } \mathrm{cm}^{2}\end{array}$ \\
\hline $\begin{array}{l}\text { Kimura et al., } \\
2014\end{array}$ & Retrospective & $2010-2011$ & $134(80 / 54)$ & $\begin{array}{c}\text { Male: } \\
66(36-86)^{* /} \\
\text { Female: } \\
66(35-81)^{*}\end{array}$ & $\begin{array}{l}\text { NSCLC, } \\
\text { III-IV }\end{array}$ & $\begin{array}{l}\text { CHT, } 12 \\
\text { months }\end{array}$ & $\begin{array}{l}\text { CT L3 } \\
\text { muscle }\end{array}$ & $\begin{array}{l}\text { Study determined } \\
1.0 \text { unit increase } \\
\text { of muscle mass } \\
\mathrm{cm}^{2} / \mathrm{m}^{2} \text { for male/ } \\
\text { female patients }\end{array}$ \\
\hline $\begin{array}{l}\text { Mitsuyoshi et al., } \\
2018\end{array}$ & Retrospective & 2006-2013 & $89(67 / 22)$ & $66(42-81)^{*}$ & $\begin{array}{l}\text { NSCLC, } \\
\text { IIIA-IIIB } \mathrm{n}\end{array}$ & $\begin{array}{c}\text { CRT, } 21 \\
\text { months (median) }\end{array}$ & $\begin{array}{l}\text { CT L3 } \\
\text { muscle }\end{array}$ & $<3.73 /<2.45$ \\
\hline $\begin{array}{l}\text { Rossi et al., } \\
2018\end{array}$ & Retrospective & $2010-2014$ & $33(6 / 27)$ & $\begin{array}{c}\text { Age }>70 \\
(12 \text { out of } \\
33 \text { patients })\end{array}$ & $\begin{array}{l}\text { NSCLC, } \\
\text { IV }\end{array}$ & $\begin{array}{l}\text { TKI, } \\
\geq 1 \text { year }\end{array}$ & $\begin{array}{l}\text { CT L3 } \\
\text { muscle }\end{array}$ & $<55 /<39$ \\
\hline $\begin{array}{l}\text { Sánchez-Lara et al., } \\
2012\end{array}$ & Prospective & 2009-2011 & $119(55 / 64)$ & $60.5 \pm 12.5$ & $\begin{array}{l}\text { NSCLC, } \\
\text { IIIB-IV }\end{array}$ & $\begin{array}{l}\text { Before } \\
\text { treatment, } \\
6 \text { months } \\
\text { (median) }\end{array}$ & $\begin{array}{l}\text { Phase } \\
\text { angle }\end{array}$ & $\begin{array}{c}\text { Phase angle }>5.8^{\circ} \\
v s . \leq 5.8^{\circ} / \text { Phase } \\
\text { angle }>5.8^{\circ} \\
v s . \leq 5.8^{\circ}\end{array}$ \\
\hline $\begin{array}{l}\text { Shoji et al., } \\
2017\end{array}$ & Retrospective & $2005-2010$ & $147(82 / 65)$ & $\begin{array}{c}68(42-86)^{*} \\
\text { T1a-T2a }\end{array}$ & NSCLC, & $\begin{array}{l}\text { Surgery/CHT, } \\
59 \text { months } \\
\text { (median) }\end{array}$ & $\begin{array}{l}\text { CT L3 } \\
\text { muscle } \\
\text { index }\end{array}$ & $<43.75 /<41.10$ \\
\hline $\begin{array}{l}\text { Sjøblom et al., } \\
2016\end{array}$ & Prospective & $2005-2006$ & $734(420 / 314)$ & $65.4 \pm 9.4$ & $\begin{array}{l}\text { NSCLC, } \\
\text { IIIB-IV }\end{array}$ & $\begin{array}{l}\text { CHT/RT, } \\
>40 \text { months }\end{array}$ & $\begin{array}{l}\text { CT L3 } \\
\text { muscle }\end{array}$ & $\begin{array}{c}<47.6,{ }^{\circ} \text { study } \\
\text { defined only a } \\
\text { threshold for male } \\
\text { patients, decrease } \\
\text { of muscle mass } \\
\text { per unit was } \\
\text { also determined }\end{array}$ \\
\hline $\begin{array}{l}\text { Stene } \text { et al., } \\
2015\end{array}$ & Prospective & 2009-2010 & $35(18 / 17)$ & $67.1 \pm 6.8$ & $\begin{array}{l}\text { NSCLC, } \\
\text { IIIB-IV }\end{array}$ & CHT, - & $\begin{array}{l}\text { CT L3 } \\
\text { muscle } \\
\text { index }\end{array}$ & $<52.4 /<38.5$ \\
\hline $\begin{array}{l}\text { Suzuki et al., } \\
2016\end{array}$ & Retrospective & $2005-2008$ & $90(52 / 38)$ & $68.7 \pm 8.7$ & $\begin{array}{l}\text { NSCLC, } \\
\text { IA-IB }\end{array}$ & $\begin{array}{l}\text { Surgery, } \\
<1 \text { year }\end{array}$ & $\begin{array}{l}\text { CT L3 } \\
\text { muscle }\end{array}$ & $\begin{array}{c}<43.75 /<41.10 \\
\text { Study used ratio }\end{array}$ \\
\hline $\begin{array}{l}\text { Takamori et al., } \\
2018\end{array}$ & Retrospective & $2005-2010$ & $101(54 / 47)$ & $\begin{array}{c}66.1 \pm 10.4 / \\
66.1 \pm 9.7\end{array}$ & NSCLC, I & $\begin{array}{l}\text { Surgery, } \\
>1 \text { year }\end{array}$ & $\begin{array}{l}\text { CT Th12 } \\
\text { muscle } \\
\text { index }\end{array}$ & $\begin{array}{l}\text { pre-operative/post- } \\
\text { operative skelettal } \\
\text { muscle area, age } \\
\text { indicated for non- } \\
\text { sarcopenic } v s . \\
\text { sarcopenic patients } \\
\text { (male/female) }\end{array}$ \\
\hline $\begin{array}{l}\text { Tsukioka et al., } \\
2017\end{array}$ & Retrospective & 2003-2012 & $215(215 / 0)$ & $68(46-93) *$ & $\begin{array}{l}\text { NSCLC, } \\
\text { IA-IIIA }\end{array}$ & $\begin{array}{l}\text { Surgery, } 6 \\
\text { months } \\
\text { (median) }\end{array}$ & $\begin{array}{l}\text { CT L3 } \\
\text { muscle } \\
\text { index }\end{array}$ & $\begin{array}{l}<49 \text {, study defined } \\
\text { only a threshold } \\
\text { for male patients }\end{array}$ \\
\hline
\end{tabular}

*Data presented as median (range). CRT, Chemoradiotherapy; CHT, chemotherapy; RT, radiation therapy. 


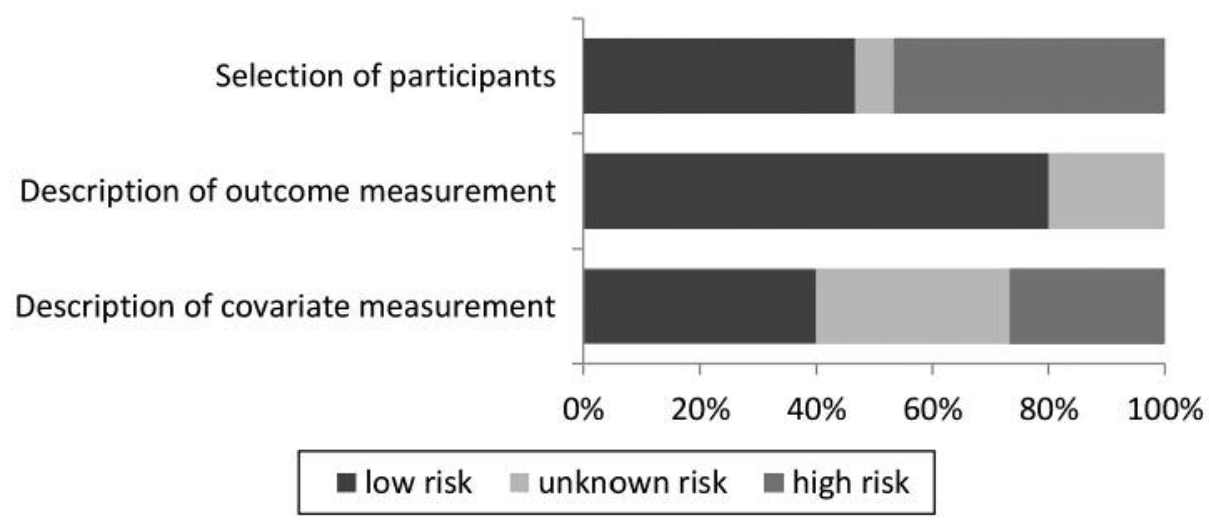

Figure 2. Quality assessment: Visualization of the risk of bias assessments of the 15 included studies. Dark grey signifies low, light grey unknown and grey high risk.

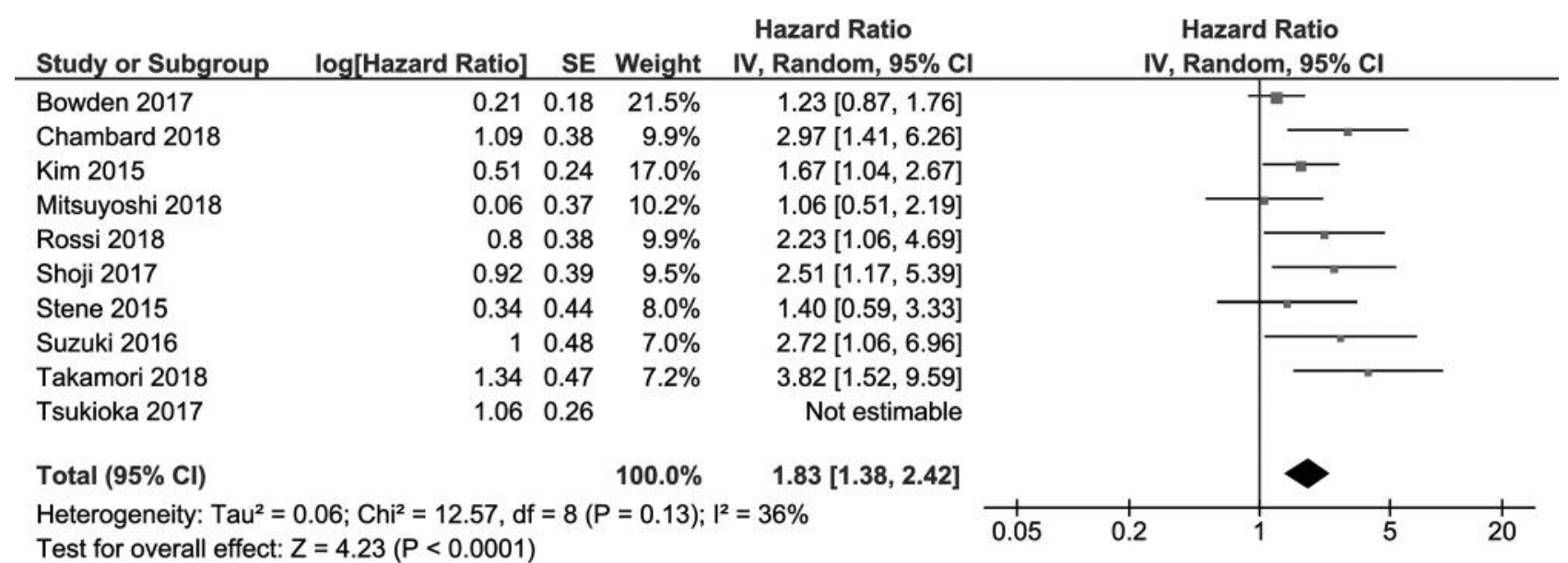

Figure 3. Pooled hazard ratios for the effect of presence of sarcopenia on the risk of death. Risk estimators from univariate analyses. The presence of sarcopenia increases the death risk of patients.

\begin{tabular}{|c|c|c|c|c|c|c|c|c|}
\hline Study or Subgroup & log[Hazard Ratio] & SE & Weight & $\begin{array}{c}\text { Hazard Ratio } \\
\text { IV, Random, } 95 \% \text { CI }\end{array}$ & \multicolumn{4}{|c|}{$\begin{array}{c}\text { Hazard Ratio } \\
\text { IV, Random, } 95 \% \mathrm{Cl}\end{array}$} \\
\hline Kim 2015 & 0.52 & 0.25 & $25.9 \%$ & $1.68[1.03,2.75]$ & & & $\square$ & \\
\hline Sanchez-Lara 2012 & 1.11 & 0.45 & $14.4 \%$ & $3.03[1.26,7.33]$ & & & & \\
\hline Shoji 2017 & 1.64 & 0.41 & $16.2 \%$ & $5.16[2.31,11.51]$ & & & & \\
\hline Stene 2015 & 0.74 & 0.74 & $6.9 \%$ & $2.10[0.49,8.94]$ & & & & \\
\hline Suzuki 2016 & 1.96 & 0.59 & $9.9 \%$ & $7.10[2.23,22.56]$ & & & & \\
\hline Takamori 2018 & 1.34 & 0.51 & $12.2 \%$ & $3.82[1.41,10.38]$ & & & & \\
\hline Tsukioka 2017 & 1.19 & 0.45 & $14.4 \%$ & $3.29[1.36,7.94]$ & & & & \\
\hline Total $(95 \% \mathrm{Cl})$ & & & $100.0 \%$ & $3.13[2.06,4.76]$ & & & & \\
\hline $\begin{array}{l}\text { Heterogeneity: } \mathrm{Tau}^{2}= \\
\text { Test for overall effect }\end{array}$ & $\begin{array}{l}11 ; \mathrm{Chi}^{2}=9.54, \mathrm{df} \\
=5.34(\mathrm{P}<0.0000\end{array}$ & $\begin{array}{l}=6(P \\
1)\end{array}$ & $=0.15) ; I^{2}$ & $=37 \%$ & 0.05 & 0.2 & 1 & 20 \\
\hline
\end{tabular}

Figure 4. Pooled hazard ratios for the effect of presence of sarcopenia on the risk of death. Risk estimators from multivariate analyses. Muscle loss increases patients' death risk. 


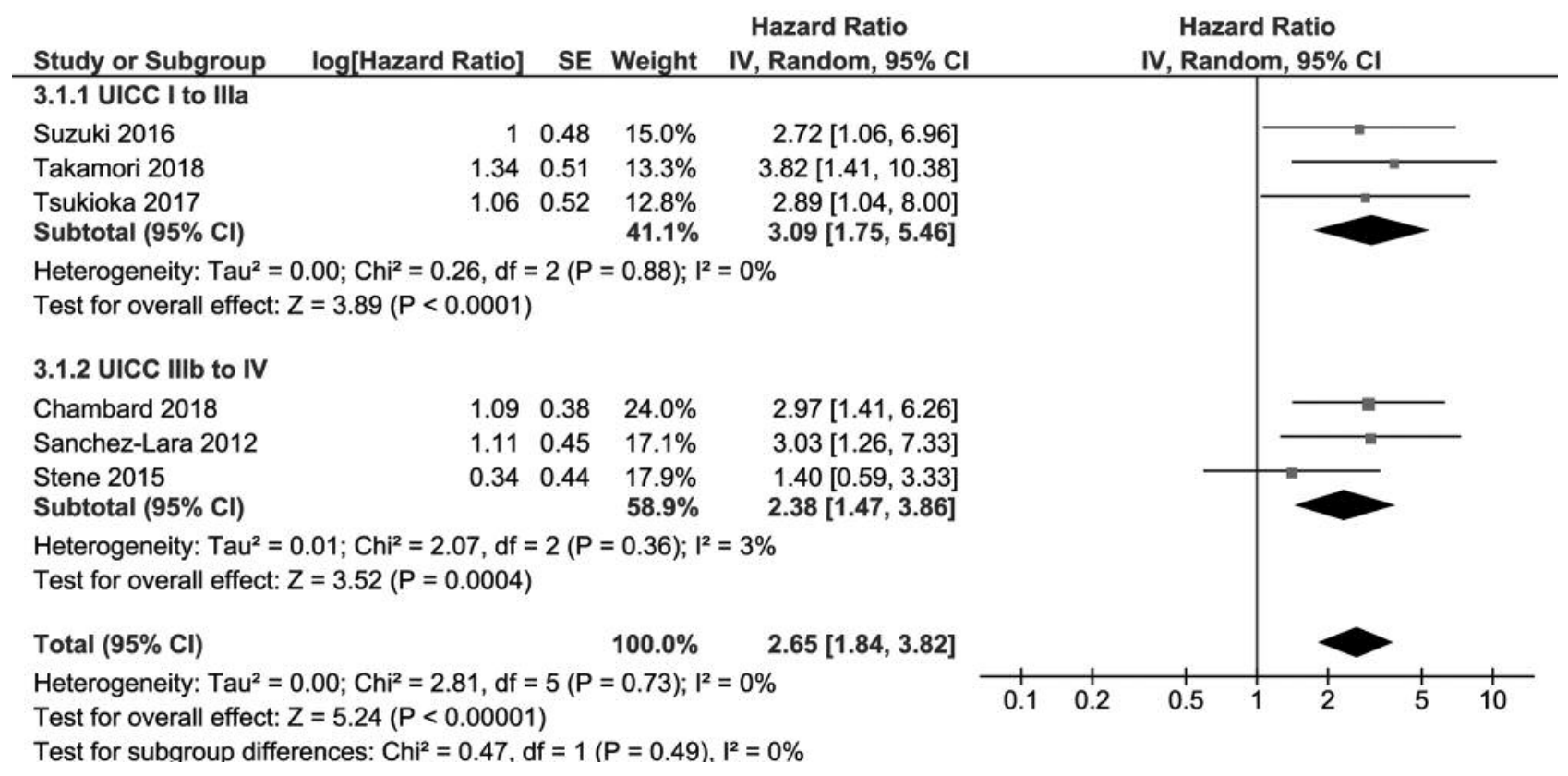

Figure 5. Pooled hazard ratios for the effect of presence of sarcopenia on the risk of death. Subgroup analysis regarding UICC classification (UICC I-IIIA and UICC IIIB-IV). Death risk of sarcopenic patients is independent of cancer stage.

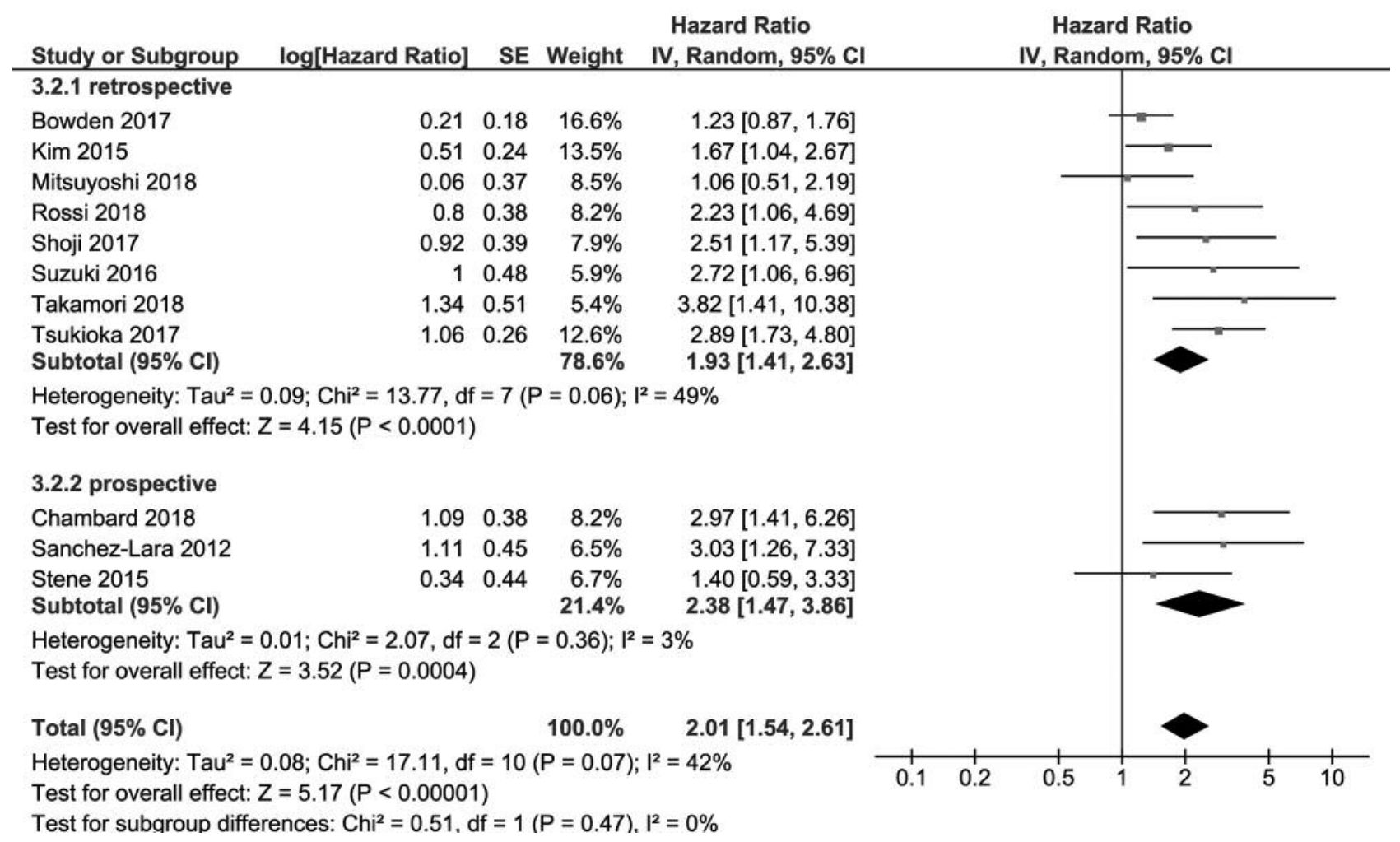

Figure 6. Pooled hazard ratios for the effect of presence of sarcopenia on the risk of death. Subgroup analysis regarding study design (retrospective and prospective studies). Study design had no impact on the influence of sarcopenia. 


\begin{tabular}{|c|c|c|c|c|c|c|c|c|}
\hline Study or Subgroup & log[Hazard Ratio] & SE & Weight & $\begin{array}{l}\text { Hazard Ratio } \\
\text { IV, Random, } 95 \% \mathrm{CI}\end{array}$ & & $\begin{array}{r}\mathrm{Ha} \\
\mathrm{IV}, \mathrm{Ra}\end{array}$ & $\begin{array}{l}\text { d Ratio } \\
\mathrm{m}, 95 \% \mathrm{Cl}\end{array}$ & \\
\hline Gupta 2009 & 0.24 & 0.105 & $2.6 \%$ & $1.27[1.03,1.56]$ & & & & \\
\hline Kimura 2015 & 0.11 & 0.03 & $18.9 \%$ & $1.12[1.05,1.18]$ & & & $\longrightarrow$ & \\
\hline Kinsey 2017 & 0.02 & 0.008 & $38.3 \%$ & $1.02[1.00,1.04]$ & & & & \\
\hline Sjoblom 2016 & 0 & 0.005 & $40.2 \%$ & $1.00[0.99,1.01]$ & & & & \\
\hline Total $(95 \% \mathrm{Cl})$ & & & $100.0 \%$ & $1.04[1.00,1.07]$ & & & & \\
\hline \multicolumn{5}{|c|}{$\begin{array}{l}\text { Heterogeneity: } \text { Tau }^{2}=0.00 ; \mathrm{Chi}^{2}=21.25, \mathrm{df}=3(P<0.0001) ; \mathrm{I}^{2}=86 \% \\
\text { Test for overall effect: } Z=1.97(P=0.05)\end{array}$} & 0.7 & 0.85 & 1.2 & 1.5 \\
\hline
\end{tabular}

Figure 7. Pooled hazard ratios for the effect of sarcopenia per 1 unit (SMA or SMI) decrease or $1^{\circ}$ phase angle decrease on the risk of death. A decrease of SMA or a phase angle leads to an elevated death risk.

Table II. Covariates of multivariate analyses

\begin{tabular}{lcl}
\hline Author & $\begin{array}{c}\text { Publication } \\
\text { year }\end{array}$ & Covariates for multivariate analysis \\
\hline Kim et al. & 2015 & Sarcopenia, age >65 years, poor performance status, elevated LDH, extensive stage, supportive care only \\
Sánchez-Lara et al. & 2012 & Not reported \\
Shoji et al. & 2017 & Not reported \\
Stene et al. & 2015 & Sarcopenia, performance status,tumour response, quality of life, appetite loss, weight loss \\
Suzuki et al. & 2016 & Sarcopenia, age, gender, smoking, BMI, performance status, cancer stage, \\
& & differentiation, surgical procedures, anemia \\
Takamori et al. & 2018 & SMA pre/post-ratio, age, BMI, vascular invasion, histological tumour type \\
Tsukioka et al. & 2017 & Sarcopenia, age, performance status, BMI, CYFRA, cancer stage \\
\hline
\end{tabular}

Results of the meta-analyses on the impact of sarcopenia on death risk of lung cancer patients. Ten studies used univariate Cox proportional hazards models for investigating the effect of the presence of sarcopenia on the risk of death The combined hazard ratio was 1.96 (95\% confidence interval $=1.49,2.59)$, indicating a significantly higher risk for death in sarcopenic patients $(p<0.001)$. The estimate of the between-study heterogeneity is $\tau^{2}=0.08$ (Figure 3 ).

Multivariate Cox proportional hazards models were used in seven studies to evaluate the risk of death in sarcopenic patients. Here, the combined hazard ratio was $3.13(95 \%$ confidence interval $=2.06,4.76$ ), pointing to a significantly shorter overall survival in the presence of sarcopenia $(p<0.001)$. The corresponding between-study heterogeneity is $\tau^{2}=0.11$ (Figure 4).

Two studies $(15,23)$ did not describe covariates, which was taken in consideration while assessing the quality of these studies. For covariates of the remaining studies please refer to Table II.

Results of subgroup analyses of cancer stage and study design. Sarcopenia is present in patients suffering from potentially curable lung cancer (UICC IA-IIIA) and in patients undergoing a palliative therapy regimen (UICC IIIB-IV). Patients of the first group (UICC IA-IIIA) have an increased risk for death of
3.09 (95\% confidence interval $=1.75,5.46, p<0.001)$ and patients of the second group (UICC IIIB-IV) of $2.38(95 \%$ confidence interval $=1.47,3.86, p<0.001)$. There is no significant difference $\left(\chi^{2}=0.47, \mathrm{df}=1, p=0.49\right)$ between the estimated death risk of both groups (Figure 5).

We included both retrospective and prospective studies. Meta-analyses of both showed a significantly elevated hazard ratio for the risk of death in sarcopenic patients (retrospective studies: $1.77(1.44,2.17), \quad p<0.001$; prospective studies: $2.38(1.48,3.83), p<0.001)$. There is no significant difference between both groups $\left(\chi^{2}=1.27, \mathrm{df}=1\right.$, $p=0.26$ ) (Figure 6).

Results of the meta-analysis of studies using a measure of sarcopenia as continuous variable. Four studies investigated the change in muscle mass as a continuous variable, measuring either the decrease in the phase angle, in muscle mass per area or in muscle mass index (SMA/SMI). A decrease of 1 unit is associated with $4 \%$ increase in risk of death $(p=0.05)$. The estimate of the between-study heterogeneity is at $\tau^{2}=0.00$ (Figure 7).

Results of sensitivity analyses. Sensitivity analyses did not result in any inconsistent results since the pooled results did not change substantially by leaving one study out and re- 
pooling the remaining studies. Therefore, the exclusion of the one study investigating small cell lung cancer did not influence the results substantially.

\section{Discussion}

Weight loss in cancer patients is usually described in the background of cancer cachexia, which is a multifactorial wasting syndrome characterized by weight loss including the ongoing loss of muscle mass with or without the loss of fat tissue. The extent of cachexia is dependent on cancer entity and stage, degree of systemic inflammation and response to anti-cancer therapy. Albeit muscle loss may predate cachexia due to aging, disuse, or inflammation (24-26).

Patients suffering from sarcopenia are of lean body mass. They may show fatigue, reduced strength and a limited physical function. With the ongoing loss of functionality, the ability to live independently may be impaired. An overlap of both cachexia and sarcopenia is possible. While usually skeletal muscle metabolism is a controlled balance of anabolic and catabolic processes, it is characterized by a procatabolic shift resulting in muscle loss and decreased protein synthesis in the presence of cachexia $(6,25,26)$. Physical activities like resistance and endurance training are recommended for patients suffering from sarcopenia. These act as anabolic stimuli, maintaining body resources under anti-cancer therapy $(2,25,26)$.

Sarcopenia is known to have an unfavourable influence on the prognosis of patients suffering from rectum, liver, oesophagus, stomach or kidney cancer $(1,7)$. Furthermore, its presence is associated with frailty, an increase of chemotoxicity and an unfavourable response to treatment $(1,8)$. Here, we assess the impact of sarcopenia on the overall survival of lung cancer patients. During the last years, several studies in lung cancer patients reported a shorter overall survival in the presence of sarcopenia $(5,11-14,18,19,27-30)$.

Studies included into this review assessed sarcopenia by computed tomography, DEXA scan or BIA. The presence of sarcopenia is a strong prognostic factor for a two-fold increased death risk of lung cancer patients (three-fold in multivariate analysis). Subgroup analyses showed no significant difference in death risk between early (UICC IIIIA) and advanced stages (UICC IIIB-IV) in the presence of sarcopenia. An explanation for the latter might be different, underlying the causes of sarcopenia. A sarcopenia concomitant to cancer cachexia is more probable in patients suffering from end stage cancer. Sarcopenia in patients undergoing a potentially curative therapeutic approach (UICCC I-IIIA) might be due to age, comorbidities, or muscle loss due to inactivity during hospitalisation.

Our meta-analyses had several limitations. This review included only observational studies. But, subgroup analysis of retrospective and prospective studies showed a significant increase in death risk in sarcopenic patients. Due to the observational character of the included studies the respective meta-analyses may be affected by the same biases found in the original studies. We included studies using different methods for assessing sarcopenia (computer tomography or DEXA scan or BIA), hence sarcopenia was defined by the design of the studies included a priori. Most of the studies using computed tomography for diagnosing sarcopenia used the L3 muscle area for acquiring the SMI, albeit one study (12) that used the pectoral and one (18) that used the Th12 muscle area. The threshold for diagnosing sarcopenia differed between studies (Table I). The study of Kim et al. used Korean-specific cut-offs for sarcopenia (11). Furthermore, the studies using BIA defined different cut-offs for sarcopenia.

From our results we concluded that sarcopenia is a prognostic factor for a poor prognosis in lung cancer patients independent of cancer stage. Patients with sarcopenia show more toxicity and less response to chemotherapy regimens (1, 8 ), while their lifespan is shorter compared to the controls. This argues for implementing screening for sarcopenia into cancer care. Identifying patients suffering from sarcopenia is a first step to acknowledge the increased risk for chemotoxicity and subsequently improve and adapt supportive care of these patients. Modern tools like smartphones are already used in patients with metastatic breast cancer for implementing a personalized physical activity program (9). Use of Health Apps increases the physical activity of patients (31). Physical activity does not only prevent muscle wasting, but also reduces cancer fatigue (10); Health Apps may help to adapt to the individual need of the patient. As sarcopenia and cancer cachexia may overlap, screening for malnutrition and nutritional intervention are other tools to decrease muscle wasting (25). Furthermore, patients suffering from metastatic NSCLC benefit from implementing early palliative care, which results in a longer survival and clinically meaningful improvement in quality of life and mood (32).

\section{Conflicts of Interest}

The Authors declare no conflict of interest regarding to the work of this manuscript.

\section{Authors' Contributions}

J.H. and C.R. did statistical analysis. J.B. and A.E. screened papers and extracted data. A.B., A.E., C.B., J.B., J.H. wrote the manuscript. C.B., J.B. and J.H. designed tables. M. H., I. K., Hassina. B., S.S., H.B. J.B. and J.H. revised and edited the manuscript. A.E., I. K. and M.H. supervised the project.

\section{Acknowledgements}

This work was supported by the publication fund of the GeorgAugust University Göttingen. JB has a scholarship of the "Göttinger 
Kolleg für Translationale Medizin”, funded by the Ministery of Science and Culture of Lower Saxony (Niedersächsischen Ministerium für Wissenschaft und Kultur).

\section{References}

1 Bozzetti F: Forcing the vicious circle: sarcopenia increases toxicity, decreases response to chemotherapy and worsens with chemotherapy. Ann Oncol 28: 2107-2118, 2017. PMID: 28911059. DOI: $10.1093 /$ annonc/mdx271

2 Ebner N and Haehling S von: Kachexie und Sarkopenie bei chronischer Herzinsuffizienz. Internist 59: 439-444, 2018 PMID: 29637239. DOI: 10.1007/s00108-018-0408-3

3 Baumgartner RN, Koehler KM, Gallagher D, Romero L, Heymsfield SB, Ross RR, Garry PJ and Lindeman RD: Epidemiology of sarcopenia among the elderly in New Mexico. Am J Epidemiol 147: 755-763, 1998. PMID: 9554417. DOI: 10.1093/oxfordjournals.aje.a009520

4 Villaseñor A, Ballard-Barbash R, Baumgartner K, Baumgartner R, Bernstein L, McTiernan A and Neuhouser ML: Prevalence and prognostic effect of sarcopenia in breast cancer survivors: the HEAL Study. J Cancer Surviv Res Pract 6: 398-406, 2012 PMID: 23054848. DOI: 10.1007/s11764-012-0234-x

5 Stene GB, Helbostad JL, Amundsen T, Sørhaug S, Hjelde H, Kaasa $\mathrm{S}$ and Grønberg BH: Changes in skeletal muscle mass during palliative chemotherapy in patients with advanced lung cancer. Acta Oncol 54: 340-348, 2015. PMID: 25225010. DOI: 10.3109/0284186X.2014.953259

6 Dodson S, Baracos VE, Jatoi A, Evans WJ, Cella D, Dalton JT and Steiner MS: Muscle wasting in cancer cachexia: Clinical implications, diagnosis, and emerging treatment strategies. Annu Rev Med 62: 265-279, 2011. PMID: 20731602. DOI: 10.1146/ annurev-med-061509-131248

7 Shachar SS, Williams GR, Muss HB and Nishijima TF: Prognostic value of sarcopenia in adults with solid tumours: A meta-analysis and systematic review. Eur J Cancer 57: 58-67, 2016. PMID: 26882087. DOI: 10.1016/j.ejca.2015.12.030

8 Chindapasirt J: Sarcopenia in cancer patients. Asian Pac J Cancer Prev APJCP 16: 8075-8077, 2015. PMID: 26745041. DOI: $10.7314 /$ apjcp.2015.16.18.8075

9 Delrieu L, Pérol O, Fervers B, Friedenreich C, Vallance J, Febvey-Combes O, Pérol D, Canada B, Roitmann E, Dufresne A, Bachelot T, Heudel P-E, Trédan O, Touillaud M and Pialoux $\mathrm{V}$ : A personalized physical activity program with activity trackers and a mobile phone app for patients with metastatic breast cancer: Protocol for a Single-Arm Feasibility Trial. JMIR Res Protoc 7: e10487, 2018. PMID: 30166274. DOI: 10.2196/ 10487

10 Bower JE: Cancer-related fatigue--mechanisms, risk factors, and treatments. Nat Rev Clin Oncol 11: 597-609, 2014. PMID: 25113839. DOI: 10.1038/nrclinonc.2014.127

11 Kim EY, Kim YS, Park I, Ahn HK, Cho EK and Jeong YM: Prognostic significance of CT-determined sarcopenia in patients with small-cell lung cancer. J Thorac Oncol 10: 1795-1799, 2015. PMID: 26484630. DOI: 10.1097/JTO.0000000000000690

12 Kinsey CM, San José Estépar R, van der Velden J, Cole BF, Christiani DC and Washko GR: Lower pectoralis muscle area is associated with a worse overall survival in non-small cell lung cancer. Cancer Epidemiol Biomark Prev 26: 38-43, 2017. PMID: 27197281. DOI: 10.1158/1055-9965.EPI-15-1067
13 Mitsuyoshi T, Matsuo Y, Itou H, Shintani T, Iizuka Y, Kim YH and Mizowaki T: Evaluation of a prognostic scoring system based on the systemic inflammatory and nutritional status of patients with locally advanced non-small-cell lung cancer treated with chemoradiotherapy. J Radiat Res 59: 50-57, 2018. PMID: 29182777. DOI: $10.1093 /$ jrr/rrx060

14 Rossi S, Di Noia V, Tonetti L, Strippoli A, Basso M, Schinzari G, Cassano A, Leone A, Barone C and D'Argento E: Does sarcopenia affect outcome in patients with non-small-cell lung cancer harboring EGFR mutations? Future Oncol 14: 919-926, 2018. PMID: 29528255. DOI: 10.2217/fon-2017-0499

15 Shoji F, Matsubara T, Kozuma Y, Haratake N, Akamine T, Takamori S, Katsura M, Toyokawa G, Okamoto T and Maehara Y: Relationship between preoperative sarcopenia status and immuno-nutritional parameters in patients with early-stage nonsmall cell lung cancer. Anticancer Res 37: 6997-7003, 2017. PMID: 29187486. DOI: 10.21873/anticanres.12168

16 Sjøblom B, Grønberg BH, Wentzel-Larsen T, Baracos VE, Hjermstad MJ, Aass N, Bremnes RM, Fløtten $\varnothing$, Bye A and Jordhøy M: Skeletal muscle radiodensity is prognostic for survival in patients with advanced non-small cell lung cancer. Clin Nutr 35: 1386-1393, 2016. PMID: 27102408. DOI: 10.1016/j.clnu.2016. 03.010

17 Suzuki Y, Okamoto T, Fujishita T, Katsura M, Akamine T, Takamori S, Morodomi Y, Tagawa T, Shoji F and Maehara Y: Clinical implications of sarcopenia in patients undergoing complete resection for early non-small cell lung cancer. Lung Cancer 101: 92-97, 2016. PMID: 27794415. DOI: 10.1016/ j.lungcan.2016.08.007

18 Takamori S, Toyokawa G, Okamoto T, Shimokawa M, Kinoshita F, Kozuma Y, Matsubara T, Haratake N, Akamine T, Takada K, Katsura M, Hirai F, Shoji F, Tagawa T, Oda Y, Honda H and Maehara Y: Clinical impact and risk factors for skeletal muscle loss after complete resection of early non-small cell lung cancer. Ann Surg Oncol 25: 1229-1236, 2018. PMID: 29327178. DOI: 10.1245/s 10434-017-6328-y

19 Tsukioka T, Nishiyama N, Izumi N, Mizuguchi S, Komatsu H, Okada S, Toda M, Hara K, Ito R and Shibata T: Sarcopenia is a novel poor prognostic factor in male patients with pathological Stage I non-small cell lung cancer. Jpn J Clin Oncol 47: 363368, 2017. PMID: 28158497. DOI: 10.1093/jjco/hyx009

20 Sanderson S, Tatt ID and Higgins JPT: Tools for assessing quality and susceptibility to bias in observational studies in epidemiology: a systematic review and annotated bibliography. Int J Epidemiol 36: 666-676, 2007. PMID: 17470488. DOI: 10.1093/ije/dym018

21 DerSimonian R and Laird N: Meta-analysis in clinical trials. Control Clin Trials 7: 177-188, 1986. PMID: 3802833.

22 DerSimonian R and Laird N: Meta-analysis in clinical trials revisited. Contemp Clin Trials 45: 139-145, 2015. PMID: 26343745. DOI: 10.1016/j.cct.2015.09.002

23 Sánchez-Lara K, Turcott JG, Juárez E, Guevara P, NúñezValencia C, Oñate-Ocaña LF, Flores D and Arrieta O: Association of nutrition parameters including bioelectrical impedance and systemic inflammatory response with quality of life and prognosis in patients with advanced non-small-cell lung cancer: a prospective study. Nutr Cancer 64: 526-534, 2012. PMID: 22489794. DOI: 10.1080/01635581.2012.668744

24 Collins J, Noble S, Chester J, Coles B and Byrne A: The assessment and impact of sarcopenia in lung cancer: a systematic literature review. BMJ Open 4: e003697, 2014. PMID: 24384894. DOI: $10.1136 /$ bmjopen-2013-003697 
25 Arends J, Bachmann P, Baracos V, Barthelemy N, Bertz H, Bozzetti F, Fearon K, Hütterer E, Isenring E, Kaasa S, Krznaric Z, Laird B, Larsson M, Laviano A, Mühlebach S, Muscaritoli M, Oldervoll L, Ravasco P, Solheim T, Strasser F, de van der Schueren $\mathrm{M}$ and Preiser J-C: ESPEN guidelines on nutrition in cancer patients. Clin Nutr 36: 11-48, 2017. PMID: 27637832. DOI: 10.1016/j.clnu.2016.07.015

26 Arends J, Baracos V, Bertz H, Bozzetti F, Calder PC, Deutz NEP, Erickson N, Laviano A, Lisanti MP, Lobo DN, McMillan DC, Muscaritoli M, Ockenga J, Pirlich M, Strasser F, de van der Schueren M, Van Gossum A, Vaupel P and Weimann A: ESPEN expert group recommendations for action against cancer-related malnutrition. Clin Nutr 36: 1187-1196, 2017. PMID: 28689670. DOI: $10.1016 /$ j.clnu.2017.06.017

27 Bowden JCS, Williams LJ, Simms A, Price A, Campbell S, Fallon MT and Fearon KCH: Prediction of 90 day and overall survival after chemoradiotherapy for lung cancer: role of performance status and body composition. Clin Oncol 29: 576584, 2017. PMID: 28652093. DOI: 10.1016/j.clon.2017.06.005

28 Chambard L, Girard N, Ollier E, Rousseau J-C, Duboeuf F, Carlier M-C, Brevet M, Szulc P, Pialat JB, Wegrzyn J, Clezardin $\mathrm{P}$ and Confavreux $\mathrm{CB}$ : Bone, muscle, and metabolic parameters predict survival in patients with synchronous bone metastases from lung cancers. Bone 108: 202-209, 2018. PMID: 29337225. DOI: $10.1016 / \mathrm{j}$. bone.2018.01.004

29 Gupta D, Lammersfeld CA, Vashi PG, King J, Dahlk SL, Grutsch JF and Lis CG: Bioelectrical impedance phase angle in clinical practice: implications for prognosis in stage IIIB and IV non-small cell lung cancer. BMC Cancer 9: 37, 2009. PMID: 19175932. DOI: $10.1186 / 1471-2407-9-37$
30 Suzuki Y, Okamoto T, Fujishita T, Katsura M, Akamine T, Takamori S, Morodomi Y, Tagawa T, Shoji F and Maehara Y: Clinical implications of sarcopenia in patients undergoing complete resection for early non-small cell lung cancer. Lung Cancer 101: 92-97, 2016. PMID: 27794415. DOI: 10.1016/ j.lungcan.2016.08.007

31 Short CE, Finlay A, Sanders I and Maher C: Development and pilot evaluation of a clinic-based mHealth app referral service to support adult cancer survivors increase their participation in physical activity using publicly available mobile apps. BMC Health Serv Res 18: 27, 2018. PMID: 29338722. DOI: 10.1186/ s12913-017-2818-7

32 Temel JS, Greer JA, Muzikansky A, Gallagher ER, Admane S, Jackson VA, Dahlin CM, Blinderman CD, Jacobsen J, Pirl WF, Billings JA and Lynch TJ: Early palliative care for patients with metastatic non-small-cell lung cancer. N Engl J Med 363: 733742, 2010. PMID: 20818875. DOI: 10.1056/NEJMoa1000678
Received June 26, 2019

Revised July 11, 2019

Accepted July 12, 2019 